\title{
Microwave Assisted Synthesis, Antimicrobial and Anti-inflammatory Potential of Some Novel 1,2,4-triazole Derivatives
}

\author{
Ankita V. Chitruk*, Akshay R. Yadav, Priyanka P. Rode, Dr. Shrinivas K. Mohite, Dr. Chandrakant S. Magdum
}

Department of Pharmaceutical Chemistry, Rajarambapu College of Pharmacy, Kasegaon, Maharashtra, India

Corresponding author E-mail:- ankitachitruk@gmail.com, akshayyadav24197@gmail.com

\author{
Article Info \\ Volume 7, Issue 4 \\ Page Number: 360-367 \\ Publication Issue : \\ July-August-2020
}

\section{Article History}

Accepted : 20 Aug 2020

Published : 30 Aug 2020

\section{ABSTRACT}

A series of 1,2,4-triazole derivatives were synthesized under microwave irradiation and characterized by IR, NMR, and mass spectral data. Pathogenic microorganisms are causative agents for different types of serious infectious diseases. Despite advancements in medication, bacterial infections continue to be a growing problem in health care. As more and more bacteria become resistant to antibiotics used in therapy there is considerable interest in the development of new compounds with antimicrobial activity. Inflammation is a central part of the response to injury and infection in the immune system. It may become problematic if the inflammatory process continues for too long. External infections involving the skin and wound are the most frequent complications affecting humans and animals. The compounds containing a heterocyclic ring play an important role among organic compounds with biological activity used as drugs in human, veterinary medicine or as insecticides and pesticides in agriculture. The compounds were evaluated for antimicrobial and anti-inflammatory activity. The pharmacological evaluation of 1,2,4-triazole derivatives revealed that, among all the compounds screened compound code $2 \mathrm{~b}$ showed leading antibacterial activity against the selected pathogenic strains of bacteria and compound code $2 \mathrm{e}$ were found to have promising anti-inflammatory activity.

Keywords: 1,2,4-triazole, microwave irradiation, antimicrobial screening, antiinflammatory activity.

\section{INTRODUCTION}

Nitrogen containing heterocycles comprising of triazoles, benzothiazoles, benzimidazoles, indoles, etc. constitute an important scaffold in biological science and medicinal chemistry, and has fascinating applications in drug discovery and development ${ }^{1}$. In particular, the synthesis of 1,2,4-triazoles has attracted considerable attention during the last years. Several potent pharmacological properties such as anti-bacterial, antimicrobial, antioxidant, anticancer, and antitubercular of 1,2,4-triazole derivatives have 
been reported ${ }^{2-4}$. Microwave chemistry is the science of applying microwave radiation to chemical reactions. Microwave assisted organic synthesis has as a new "lead" in the organic synthesis ${ }^{5-7}$. This technique offers clean, simple, efficient, fast and economic for the synthesis of a number of organic molecules such reaction has new tool in the organic synthesis. Important advantage of this technology includes highly accelerated rate of the reaction time with an improvement in yield and quality of product ${ }^{8}$. Experiments have proved that microwave method, in comparison with the Soxhlet extraction, use a lesser volume of solvent and sample and perform extraction at a much faster rate were previously reported for various plant extractions. Due to failure of ADME so it necessary to perform docking studies before pharmacological activity for triazole molecules. An outbreak of coronavirus disease (COVID-19) caused by the novel severe acute respiratory syndrome coronavirus-2 (SARS-CoV-2) raises an unparalleled challenge in the discovery of appropriate drugs for prevention and treatment. Given the rapid pace of scientific research and clinical data produced by the large number of people quickly infected with SARSCoV-2, clinicians need reliable proof of successful medical care for this infection as in this pandemic insilico docking studies of 1,2,4-triazole have shown good results. The chemical modification of drug delivery system for protein and peptide drugs is important in improving both enzymatic stability and membrane permeations can help to have good biological activity from any heterocyclic compound modification. Someday soon, you might be making your own medicines at home. That's because researchers have tailored a $3 \mathrm{D}$ printer to synthesize pharmaceuticals and other chemicals from simple, widely available starting compounds fed into a series ${ }^{9-}$ 22. The search for newer sources of antibiotics is a global challenge pre-occupying research institutions, pharmaceutical companies, and academia, since many infectious agents are becoming resistant to synthetic drugs. Emergence of resistant strains of pathogenic microorganism has also continued to pose a major health concern about the efficacy of several drugs, most importantly antibiotics in current use. At present lot of drugs are accessible for curing the microbial infection but most of them is becoming abortive due to antimicrobial resistance by the microorganisms. So there is an immense need for the discovery of novel antimicrobial agents to overcome the antimicrobial resistance and side effects ${ }^{23-25}$. Inflammation is a complex biological response of vascular tissue to harmful stimuli, pathogens, irritants characterized by redness, warmth, swelling and pain Prolonged inflammation leads to the rheumatoid arthritis, atherosclerosis, hay fever, ischemic heart diseases etc and inflammation is a common manifestation of infectious diseases like leprosy, tuberculosis, asthma, inflammatory bowel syndrome, nephritis, vascularitis, celiac diseases and autoimmune diseases etc. In this research article, we have reported the microwave assisted synthesis of new 1,2,4-triazole derivatives. These compounds were tested for antimicrobial and anti-inflammatory activity $^{26}$.

\section{MATERIAL AND METHODS}

All chemicals and solvents were procured from commercial sources, purified and dried using standard procedures from literature whenever required the regents were purchased from S. D fine, research laboratory and merck laboratory, Mumbai. The melting points of synthesized compound were determined by open capillary tube method and are uncorrected. Thin layer chromatography was used confirmation of reaction and the purity of the intermediate and the final compounds by applying a single spot on TLC plate (silica gel G) using various solvents such as butanol, chloroform, water system. TLC plates were visualized under iodine chamber. IR spectra were recorded on FTIR, NMR spectra were 
performed in DMSO solution using Bruker $300 \mathrm{MHz}$ and their chemical shift are reported in $\delta$ unit with respect to TMS as internal standard. Mass spectra were recorded on Pe sciex (model no. API 2000) software analyst 1.4.2 mode: Q1MS Q1/AUTO INJECTION from diya lab, airoli, Mumbai. General preocedure for synthesis of 1,2,4-triazole derivatives are as follows:

General method for the Synthesis of 2-(2substituted)hydrazine carbodithioic acid

Mixture of substituted benzhydrazide (2g) and carbon disulphide $(1.5 \mathrm{ml})$ was irradiated for $15 \mathrm{~min}$ at 340 watt under microwave. The reaction was monitored by TLC using chloroform: methanol (9:1) as mobile phase.

General method for the Synthesis of 4-amino-5(substituted phenyl)-4H-1,2,4-triazole-3-thiol

A product of 2-(2-substituted)hydrazine carbodithioic acid was added in hydrazine hydrate $(2 \mathrm{ml})$ and methanol $(10 \mathrm{ml})$ and mixture was irradiated for 20 min at 340 watt under microwave. The reaction was monitored by TLC using butane: chloroform: water (7:2:1) as mobile phase. The solid product was washed with water and recrystallized with methanol.

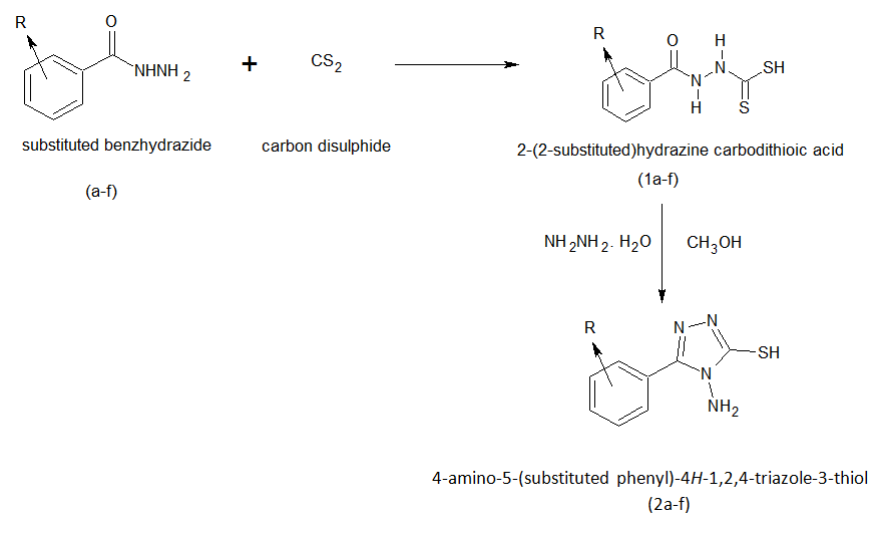

Scheme 1: Synthetic route for the preparation of the title compound (2a-f)
Analytical Data of Novel 4-amino-5-(substituted phenyl)-4H-1,2,4-triazole-3-thiol Derivatives:

2a. 4-amino-5-(4-nitrophenyl)-4H-1,2,4-triazole-3thiol

Yield 72\%; m.p $150-152^{\circ} \mathrm{C}$; IR $\left(\mathrm{KBr}, \mathrm{cm}^{-1}\right) 1338.12$ (AR-NO2), 1651.54 (C=C), 2253.32 (C-C), 2485.11 (S$\mathrm{H}), 1 \mathrm{H}$ NMR (DMSO, 300MHz, ppm): $\delta 2.20$ (s, 1H), 5.59-5.68 (d, 2H, ArH), 7.40-7.47 (q, 4H, ArH); mass $\mathrm{m} / \mathrm{z}(\mathrm{M}+)$ 237.3.

2b. 4-amino-5-(chloromethyl)-4H-1,2,4-triazole-3thiol

Yield 67\%; m.p 142-1440 $\mathrm{C}$; IR (KBr, $\left.\mathrm{cm}^{-1}\right) 669.12$ (C$\mathrm{Cl}), 1630.72(\mathrm{C}=\mathrm{C}), 2490.72(\mathrm{~S}-\mathrm{H}), 1 \mathrm{H}$ NMR (DMSO, $300 \mathrm{MHz}, \mathrm{ppm}): \delta 2.81$ (s, 1H), 5.35-5.40 (d, 2H, ArH); mass $\mathrm{m} / \mathrm{z}(\mathrm{M}+)$ 164.7.

2c. 4-amino-5-(chlorosulfanyl)-4H-1,2,4-triazole-3thiol

Yield 63\%; m.p 147-1490 C; IR (KBr, $\left.\mathrm{cm}^{-1}\right) 752.81$ (CS), $2460.31(\mathrm{~S}-\mathrm{H}), 3452.18(\mathrm{~N}-\mathrm{H}), 1 \mathrm{H}$ NMR (DMSO, $300 \mathrm{MHz}, \mathrm{ppm}): \delta 2.28$ (s, $1 \mathrm{H}), 5.58-5.65(\mathrm{~d}, 2 \mathrm{H}, \mathrm{ArH})$; mass $\mathrm{m} / \mathrm{z}(\mathrm{M}+)$ 182.4.

2d. 4-amino-5-[4-(trifluoromethyl)phenyl]-4H-1,2,4triazole-3-thiol

Yield 83\%; m.p $155-157^{\circ} \mathrm{C}$; IR (KBr, cm-1) 1671.42 $(\mathrm{C}=\mathrm{C}), 2240.18$ (C-C), 2443.72 (S-H), 1H NMR (DMSO, 300MHz, ppm): $\delta 2.40$ (s, 1H), 5.49-5.58 (d, $2 \mathrm{H}, \operatorname{ArH}), 7.39-7.48$ (q, $4 \mathrm{H}, \mathrm{ArH}) ;$ mass $\mathrm{m} / \mathrm{z}(\mathrm{M}+)$ 260.3.

2e. 4-amino-5-(2,4-dimethoxyphenyl)-4H-1,2,4triazole-3-thiol

Yield 78\%; m.p $152-154^{\circ} \mathrm{C}$; IR (KBr, cm-1) 1679.35 (C=C), 2253.87 (C-C), 2471.19 (S-H), 1H NMR (DMSO, 300MHz, ppm): $\delta 2.51$ (s, 1H), 5.49-5.57 (d, $2 \mathrm{H}, \mathrm{ArH}), 7.41-7.58$ (q, 4H, d, ArH); mass m/z (M+) 252.3.

2f. 4-amino-5-[4-(dimethylamino)phenyl]-4H-1,2,4triazole-3-thiol

Yield 87\%; m.p $167-169^{\circ} \mathrm{C}$; IR (KBr, cm- $\left.{ }^{-1}\right) 1651.49$ $(\mathrm{C}=\mathrm{C}), 2817.12\left(\mathrm{~N}-\mathrm{CH}_{3}\right), 2244.52(\mathrm{C}-\mathrm{C}), 2469.11(\mathrm{~S}-\mathrm{H})$, $1 \mathrm{H}$ NMR (DMSO, 300MHz, ppm): $\delta 2.40$ (s, 1H), 
3.25-3.21 (t, 2H, ArH), 5.31-5.38 (d, 2H, ArH), 7.627.69 (q, 4H, ArH); mass m/z (M+) 235.4.

\section{BIOLOGICAL EVALUATION:}

\section{A. Antimicrobial screening:}

\section{Chemicals}

All chemicals and solvent where procured from commercial sources, purified and sterilize using standard procedure from literature whenever required.

\section{Dilution of compound}

All the synthesized compound where dissolved in dimethyl sulphoxide [DMSO] so as to get concentration of $100 \mu \mathrm{g} / \mathrm{ml}$ and $200 \mu \mathrm{g} / \mathrm{ml}$, and standard drug ciprofloxacin in DMSO as a concentration of $200 \mu \mathrm{g} / \mathrm{ml}$.

\section{Sterilization of equipment and the chemicals}

MacConkey agar, Nutrient agar medium [NO11], Normal saline solution where sterilized in autoclave. At 15 Ibs pressure [12IC] for $150 \mathrm{~min}$. Petri plates, Whatman filter paper, descant cotton swabs where sterilized in oven at $160^{\circ} \mathrm{C}$ for $2 \mathrm{hrs}$.

\section{Preparation of MacConkey agar slant}

MacConkey agar $206 \mathrm{mg}$ was dissolved in $4 \mathrm{ml}$ of distilled water, boiled and poured test tube then plugged with cotton and sterilize in autoclave as 15 Ibs pressure $121^{\circ} \mathrm{C}$ for $15 \mathrm{~min}$. After sterilization the tubes containing the MacConkeys agar were kept in inclined position from $30 \mathrm{~min}$. Then on the surface of slants pure culture staphylococcus aureus where streaked in aseptic condition and incubated and $37^{\circ} \mathrm{C}$ for the 24 hours.

\section{Preparation of nutrient agar medium slant}

Nutrient agar medium $112 \mathrm{mg}$ and agar powder 100 $\mathrm{mg}$ was dissolved in $4 \mathrm{ml}$ distilled water, boiled and then poured in test tube then plugged with cotton and sterilized in autoclave at $15 \mathrm{Ibs}$ pressure $\left(121^{\circ} \mathrm{C}\right)$ for $15 \mathrm{~min}$. After the sterilization the tubes containing the nutrient agar medium were kept in inclined position for $30 \mathrm{~min}$. Then on the surface of slants pure culture of E.coli were streaked in aseptic condition and incubated at $37^{\circ} \mathrm{C}$ for 24 hours.

\section{Preparation of suspension of test bacteria:}

Using the 24 hours old growth of test bacteria from the slant, suspension of bacteria was made separately in sterile normal saline solution $(0.85 \% \mathrm{NaCl}$ in distilled water) in aseptic condition, to get moderate turbidity. The turbidity of each suspension was compared adjusted with the turbidity of the solution resulting by mixing $0.5 \mathrm{ml}$ of $1.175 \%$ of barium chloride and $99.5 \mathrm{mi}$ of $36 \mathrm{~N}$ of $\mathrm{H}_{2} \mathrm{SO}_{4}$.

\section{Method: Disc Diffusion Method}

\section{Preparation of culture media for antibacterial sensitivity test}

MacConkey agar (50ml) and nutrient agar (100ml) was prepared as per the procedure given for preparation of slants respectively. Then it was sterilized in autoclave at $15 \mathrm{lbs}$ pressure $\left(121^{\circ} \mathrm{C}\right)$ for 15 min. after sterilization the media was cooled up to $45^{\circ} \mathrm{C}$, poured $20-25 \mathrm{ml}$ in sterile Petri plates in aseptic condition and allowed to solidify.

\section{Inoculation of suspension of bacteria on culture media}

Sterile, non toxic swab were dipped into the standardized inoculums and then the entire agar surface of the plate was streaked with the swab three times, turning the plate at 60 angles between streaking. Then the streaked inoculum was allowed to dry for 5-15 min with lid. Sterile Whatman paper disc dipped separately into the solutions containing synthesized drug $(100 \mu \mathrm{g} / \mathrm{ml}$ and $200 \mu \mathrm{g} / \mathrm{ml})$ and 
standard drug ciprofloxacin $(100 \mu \mathrm{g} / \mathrm{ml}$ and $200 \mu \mathrm{g} / \mathrm{ml})$ in aseptic condition with the help of sterile forceps and placed on the surface of inoculated culture media after which the plates were kept in refrigeration for $30 \mathrm{~min}$. for the diffusion of the compound from the paper disc into the culture media. After $30 \mathrm{~min}$. The plates were incubated at $37^{\circ} \mathrm{C}$ for $24 \mathrm{hrs}$. All the synthesized compounds (2a-f) were observed for antibacterial activity. Observation was recorded in tables by measuring the zone of inhibition in millimeters ${ }^{27}$.

\section{B. Anti-inflammatory Evaluation}

Method: Protein denaturation method

The mixture $(5 \mathrm{ml})$ consisted of $0.2 \mathrm{ml}$ of egg albumin (from fresh hen's egg), $2.8 \mathrm{ml}$ of Phosphate buffered solution (PBS, $\mathrm{pH}$ 6.4) and $2 \mathrm{ml}$ of varying concentration of test samples so that final concentration become $50 \mu \mathrm{g} / \mathrm{ml}$ and $100 \mu \mathrm{g} / \mathrm{ml}$. Similar volume of DMSO served as control. Then the mixtures were incubated at $\left(37^{\circ} \mathrm{C} \pm 2\right)$ for $15 \mathrm{~min}$. and then heated at $70^{\circ} \mathrm{C}$ for $5 \mathrm{~min}$. After cooling, their absorbance was measured at $660 \mathrm{~nm}$ (JASCO UV spectrophotometer) by using vehicle as blank and their viscosity was determined by using ostwald viscometer. Diclofenac at the final concentration of $50 \mu \mathrm{g} / \mathrm{ml}$ and $100 \mu \mathrm{g} / \mathrm{ml}$ was used as reference drug and treated similarly for determination of absorbance and viscosity.

The $\%$ inhibition of protein denaturation was calculated by using the following formula ${ }^{28-29}$.

$\%$ inhibition protein denaturation $=$ Absorbance of control - Absorbance of test

Absorbance of control

\section{RESULT AND DISCUSSION}

\section{Chemistry}

In first step mixture of substituted benzhydrazide and carbon disulphide was irradiated for $15 \mathrm{~min}$ at 340 watt under microwave. The reaction was monitored by TLC using chloroform: methanol (9:1) as mobile phase. A product of 2-(2-substituted)hydrazine carbodithioic acid was added in hydrazine hydrate and methanol and mixture was irradiated for $20 \mathrm{~min}$ at 340 watt under microwave. The reaction was monitored by TLC using butane: chloroform: water (7:2:1) as mobile phase. The solid product was washed with water and recrystallized with methanol. The reaction sequence is shown in Scheme 1. Microwave assisted synthesis is faster, better and safer green chemistry approach for the traditional reactions. The time taken for the synthesis of 1,2,4-triazole is drastically reduced by the microwave assisted synthesis. This technique offers clean, simple, efficient, fast and economic for the synthesis of a number of organic molecules such reaction has new tool in the organic synthesis and highly accelerated rate of the reaction time with an improvement in yield and quality of product. The IR, NMR and mass spectra are fully consistent with the structure.

\section{Antimicrobial activity:}

Antibacterial activity of the newly synthesized compounds (2a-f) was evaluated by the disc diffusion method against Escherichia coli, Pseudomonas aeruginosa and Staphylococcus aureus strains of bacteria. Compound code $2 \mathrm{~b}$ were found to be highly active against all the tested strains of bacteria showing the broadest spectrum of antibacterial activity when compared with standard drug ciprofloxacin. 
Table 1: Antibacterial screening result of synthesized compounds (2a-f) measuring the zone of inhibition in millimeter

\begin{tabular}{|c|c|c|c|c|c|c|c|}
\hline \multirow{3}{*}{$\begin{array}{l}\text { Sr. } \\
\text { No }\end{array}$} & \multirow{3}{*}{$\begin{array}{l}\text { Compound } \\
\text { code }\end{array}$} & \multicolumn{6}{|c|}{ Diameter of zone of inhibition (mm) } \\
\hline & & \multicolumn{2}{|c|}{ E. coli } & \multicolumn{2}{|c|}{$P$. aeruginosa } & \multicolumn{2}{|c|}{ S. aureus } \\
\hline & & $100 \mu \mathrm{g} / \mathrm{ml}$ & $200 \mu \mathrm{g} / \mathrm{ml}$ & $100 \mu \mathrm{g} / \mathrm{ml}$ & $200 \mu \mathrm{g} / \mathrm{ml}$ & $100 \mu \mathrm{g} / \mathrm{ml}$ & $200 \mu \mathrm{g} / \mathrm{ml}$ \\
\hline 1 & $2 \mathrm{a}$ & 12 & 15 & 9 & 13 & 16 & 18 \\
\hline 2 & $2 b$ & 19 & 27 & 16 & 19 & 22 & 25 \\
\hline 3 & $2 c$ & 10 & 13 & 8 & 14 & 12 & 15 \\
\hline 4 & $2 \mathrm{~d}$ & 14 & 19 & 11 & 12 & 17 & 19 \\
\hline 5 & $2 e$ & 8 & 11 & 10 & 13 & 10 & 14 \\
\hline 6 & $2 f$ & 16 & 21 & 7 & 11 & 8 & 12 \\
\hline 7 & Ciprofloxacin & 22 & 26 & 18 & 20 & 21 & 23 \\
\hline
\end{tabular}

\section{Anti-inflammatory activity:}

In present study in-vitro results confirmed antiinflammatory activity of new series of 1,2,4-triazole evaluated by denaturation of proteins which is a well documented cause of inflammation. Several antiinflammatory drugs shown dose dependent ability to inhibit thermally induced protein denaturation. Ability of 1,2,4-triazole is to bring down thermal denaturation of protein is possibly a contributing factor for its anti-inflammatory activity. The data of our studies suggests that compound code 2e shows significant anti-inflammatory activity.

Table 2: Anti-inflammatory activity of synthesized compounds measuring inhibition of protein denaturation

\begin{tabular}{|c|c|c|c|c|c|}
\hline \multirow[t]{2}{*}{ Sr. no } & \multirow{2}{*}{$\begin{array}{c}\text { Compound } \\
\text { code }\end{array}$} & \multicolumn{2}{|c|}{$\begin{array}{c}\% \text { inhibition of protein } \\
\text { denaturation }\end{array}$} & \multicolumn{2}{|c|}{ Viscosity (cps) } \\
\hline & & $50 \mu \mathrm{g} / \mathrm{ml}$ & $100 \mu \mathrm{g} / \mathrm{ml}$ & $50 \mu \mathrm{g} / \mathrm{ml}$ & $100 \mu \mathrm{g} / \mathrm{ml}$ \\
\hline 1 & $2 a$ & 61.35 & 63.29 & 0.44 & 0.48 \\
\hline 2 & $2 b$ & 57.73 & 71.65 & 0.40 & 0.43 \\
\hline 3 & $2 c$ & 61.67 & 63.41 & 0.42 & 0.45 \\
\hline 4 & $2 d$ & 69.31 & 70.42 & 0.48 & 0.50 \\
\hline 5 & $2 \mathrm{e}$ & 75.12 & 78.16 & 0.52 & 0.56 \\
\hline 6 & $2 f$ & 62.70 & 67.19 & 0.47 & 0.49 \\
\hline 7 & Diclofenac & 78.14 & 82.52 & 0.50 & 0.54 \\
\hline
\end{tabular}




\section{CONCLUSION}

A series of 4-amino-5-(substituted phenyl)-4H-1,2,4triazole-3-thiol were synthesized by microwave method and characterized by IR, NMR and mass spectra. All newly synthesized were screened for antibacterial activity. Among them compound code $2 \mathrm{~b}$ showed excellent antibacterial activity. The results of anti-inflammatory activity highlighted that tested compound code 2e exhibited significant activity by protein denaturation method.

\section{ACKNOWLEDGEMENT}

I express my sincere thanks to Vice-principal Prof. Dr. S. K. Mohite and Prof. Dr. C. S. Magdum for providing me all necessary facilities and valuable guidance extended to me.

\section{REFERENCES}

[1]. Khan I, Zaib S, Ibrar A, Rama A, Simpson J, Iqbal J. Synthesis, crystal structure and biological evaluation of some novel 1,2,4-triazolo-3,4-b]1,3,4-thiadiazoles and 1,2,4-triazolo-3,4-b]-1,3,4thiadiazines. Eur J Med Chem. 2014; 78: 167-177.

[2]. Chitruk A, Yadav A, Rode P, Mohite S, Magdum C. Synthesis and toxicological evaluation using brine shrimp lethality assay of Novel 1,2,4-triazole derivatives with anticancer activity. Int. J. Curr. Adv. Res. 2020; 09(08)(A): 22877-22881.

[3]. Chai X, Zhang J, Yu S. Design, synthesis, and biological evaluation of novel 1-(1H-1,2,4-triazole1-yl)-2-(2,4-difluorophenyl)-3-substituted benzylamino-2-propanols. Bioorg Med Chem Lett. 2009; 19(6): 1811-1814.

[4]. Mavrova A, Wesselinova D, Tsenov Y, Denkova P. Synthesis, cytotoxicity and effects of some 1,2,4triazole and 1,3,4-thiadiazole derivatives on immunocompetent cells. Eur J Med Chem. 2009; 44(1): 63-69.

[5]. Yadav A, Mohite S. A Brief Review: Microwave Chemistry and its Applications. Res. J. Pharma. Dosage Forms and Tech. 2020; 12(3): 191-197.

[6]. Honmane P, Yadav A, Singh S, Mohite S. Microwave Assisted Synthesis of Novel Benzimidazole Derivatives as Potent Antileishmanial and Antimalarial Agents. Int. J. Curr. Adv. Res. 2020; 09(07)(B): 22742-22746.

[7]. Yadav A, Mohite S, Magdum C. Microwave assisted synthesis of some Traditional reactions: Green chemistry approach. Asian J. Research Chem. 2020; 13(4): 275-278.

[8]. Yadav A, Mohite S, Magdum C. Comparative Study of Conventional and Microwave Assisted Synthesis of some Organic Reactions. Asian J. Pharm. Res. 2020; 10(3): 217-220.

[9]. Rode P, Yadav A, Chitruk A, Mohite S, Magdum C. Synthesis, Anticancer and Molecular Docking Studies of N-(1H-benzimidazol-2-ylcarbamothioyl)benzamide Analogues. Int. j. sci. res. sci. technol, 2020; 7(4): 204-212.

[10]. Yadav A, Mohite S. Anticancer Activity and InSilico ADMET Analysis of Malvastrum Coromandelianum. International Journal of Pharma Sciences and Research. 2020; 11(5): 71-73.

[11]. Yadav A, Mohite S. Cancer- A Silent Killer: An Overview. Asian J. Pharm. Res. 2020; 10(3): 213216.

[12]. Yadav A, Mohite S. Different Techniques and Characterization of Polymorphism with their Evaluation: A Review. Asian J. Pharm. Tech. 2020; 10(3): 213-216.

[13]. Yadav A, Mohite S. Rajput M, Suryawanshi V, Birajdar R, Patil M. Antioxidant Activity of Psidium guajava Leaf Extracts. Res. J. Pharma. Dosage Forms and Tech. 2020; 12(3): 159-161.

[14]. Yadav A, Mohite S, Magdum C. Synthesis. Characterization and Biological Evaluation of Some Novel 1,3,4-Oxadiazole Derivatives as Potential 
Anticancer Agents. Int. j. sci. res. sci. technol. 2020; 7(2): 275-282.

[15]. Yadav A, Mohite S. Green Chemistry approach for Microwave assisted synthesis of some Traditional Reactions. Asian J. Research Chem. 2020; 13(4): 261-264.

[16]. Yadav A, Mohite S. ADME analysis of phytochemical constituents of Psidium guajava. Asian J. Res. Chem. 2020; 13(5): 102-105.

[17]. Suryawanshi V, Yadav A, Birajdar R, Jagtap N, Vambhurkar G, Patil P. Optimization of ayurvedic herbal medicine by nanoformulation. Asian J. Res. Pharm. Sci. 2019; 9(1): 55-56.

[18]. Yadav A, Mohite S. A Review on severe acute respiratory infection (SARI) and its clinical management in suspect/confirmed novel coronavirus (nCoV) cases Res. J. Pharma. Dosage Forms and Tech. 2020; 12(3): 178-180.

[19]. Yadav A, Mohite S. A Review on Novel Coronavirus (COVID-19). International Journal of Pharma Sciences and Research. 2020; 11(5): 74-76.

[20]. Yadav A, Mohite S. A Novel approach for treatment of COVID-19 with Convalescent Plasma. Res. J. Pharma. Dosage Forms and Tech. 2020; 12(3): 227-230.

[21]. Yadav A, Mohite S. Recent advances in protein and peptide drug delivery. Res. J. Pharma. Dosage Forms and Tech. 2020; 12(3): 205-212.

[22]. Honmane P, Yadav A, Singh S, Mohite S. 3D printing technology in pharmaceuticals and biomedical. World J Pharm Pharm Sci. 2020; 9(9): 598-609.

[23]. Bhosale M, Yadav A, Mohite S, Magdum C. Synthesis, molecular docking studies and biological evaluation of 1,3,4-thiadiazole derivatives as antimicrobial agents. Int. J. Curr. Adv. Res. 2020; 09(08)(A): 22894-22899.

[24]. Rajput M. D, Yadav A. R, Mohite S. K. Synthesis, Characterization of Benzimidazole Derivatives as Potent Antimicrobial Agents. International Journal of Pharmacy \& Pharmaceutical Research. 2020; 17(4): 279-285.
[25]. Yadav A, Mohite S, Magdum C. Preparation and Evaluation of Antibacterial Herbal Mouthwash against Oral Pathogens. Asian J. Res. Pharm. Sci. 2020; 10(3): 149-152.

[26]. Yadav A, Mohite S. Screening of In-vitro antiinflammatory and Antibacterial assay of Malvastrum Coromandelianum. International Journal of Pharma Sciences and Research. 2020; 11(4): 68-70.

[27]. Rode P, Yadav A, Chitruk A, Mohite S, Magdum C. Microwave assisted synthesis, toxicological assessment using brine shrimp lethality assay and antimicrobial potential of new series of benzimidazole derivatives. Int. J. Curr. Adv. Res. 2020; 09(08)(A): 22900-22905.

[28]. Bhosale M, Yadav A, Magdum C, Mohite S. Molecular Docking Studies, Synthesis, Toxicological Evaluation using Brine Shrimp (Artemia salina L.) Model and Anti-inflammatory Activity of Some N-(substituted)-5-phenyl-1,3,4thiadiazol-2-amine Derivatives. Int J Sci Res Sci \& Technol. 2020; 7(5): 51-62.

[29]. Yadav A, Mohite S. Design, Synthesis and Characterization of Some Novel benzamide derivatives and it's Pharmacological Screening. Int. j. sci. res. sci. technol. 2020; 7(2): 68-74.

\section{Cite this article as :}

Ankita V. Chitruk, Akshay R. Yadav, Priyanka P. Rode, Dr. Shrinivas K. Mohite, Dr. Chandrakant S. Magdum, "Microwave Assisted Synthesis, Antimicrobial and Antiinflammatory Potential of Some Novel 1,2,4-triazole Derivatives", International Journal of Scientific Research in Science and Technology (IJSRST), Online ISSN : 2395-602X, Print ISSN : 2395-6011, Volume 7 Issue 4, pp. 360-367, July-August 2020. Available at doi : https://doi.org/10.32628/IJSRST207481 Journal URL : http://ijsrst.com/IJSRST207481 